\title{
Entangled Bystanders: Multidimensional Trauma of Ethnic Cleansing and Mass Violence in Eastern Galicia
}

\author{
Anna Wylegata
}

\section{INTRODUCTION}

The objective of the present chapter is to contribute to the discussion on individual and collective trauma by conceptualizing the multi-level trauma suffered by civilians during ethnic cleansing. Using the example of Eastern Galicia- a region that experienced ethnic cleansing on a massive scale during World War II, I will attempt to answer the following questions: what traumatizes those who witness mass and long-term ethnic violence (bystanders), what type of trauma it is, and what its long-term consequences are for the communities under study.

The level of ethnic violence in Eastern Galicia during World War II was unmatched. On the eve of World War II, Eastern Galicia was a multiethnic region that was part of the Second Polish Republic. It was primarily

\footnotetext{
A. Wylegała $(\bowtie)$

Institute of Philosophy and Sociology, Polish Academy of Sciences, Warszawa, Poland

(C) The Author(s) 2022

V. Kivimäki, P. Leese (eds.), Trauma, Experience and Narrative in Europe after World War II, Palgrave Studies in the History of Experience, https://doi.org/10.1007/978-3-030-84663-3_5
} 
inhabited by Ukrainians, had a Jewish minority of approximately ten percent of the population, mainly in cities, and a strong Polish (politically privileged) minority, which, depending on the area, constituted about 25 percent of the population. In September 1939, Galicia was annexed by the Soviet Union (USSR). The almost two-year-long occupation was initiated with murders of Polish landowners and arrests of the members of Polish elites, but repression soon touched other population groups as well. It is estimated that Soviet authorities deported at least 350,000 Polish citizens (the highest estimates point to a million) to the Soviet interior and arrested at least 100,000 in the period 1939-1941. ${ }^{1}$ Over 21,000 were killed in the so-called Katyń massacre, and at least 10,000 during the so-called prison massacres - the mass executions of political prisoners during the evacuation of Soviet prisoners at the beginning of the German-Soviet war in June 1941.2

During the German occupation, the Nazis killed at least 550,000 Jews, or 95 percent of the pre-war Jewish community, in Galicia and thus effectively committed a genocide of the Jewish population. ${ }^{3}$ Galician Jews were murdered in extermination camps located in present-day Poland (mainly in Bełżec), but more than half of them were killed on the spot, in front of their neighbors. ${ }^{4}$ The Holocaust in Galicia began immediately with the arrival of the Wehrmacht when a wave of pogroms swept through these lands, carried out by locals with the consent of German authorities. ${ }^{5}$ During Operation Reinhardt - the major killing operation of the Holocaust in the General Government implemented in 1942-1943-Germans had the support of the Ukrainian auxiliary police, but they also employed ordinary civilians, Poles and Ukrainians, for a number of additional tasks.

Ethnic cleansing of the Polish population took place in Galicia almost concurrently with the Holocaust. It was carried out by Ukrainian

${ }^{1}$ Stanisław Ciesielski, Wojciech Materski and Andrzej Paczkowski, Represje sowieckie wobec Polaków i obywateli polskich (Warszawa: Ośrodek Karta, 2002); Keith Sword, Deportation and Exile: Poles in the Soviet Union, 1939-48 (London: St. Martin's Press, 1994).

${ }^{2}$ Ksenya Kiebuzinski and Alexander Motyl, The Great West Ukrainian Prison Massacre of 1941: A Sourcebook (Amsterdam: Amsterdam University Press, 2017).

${ }^{3}$ Alexander Kruglov, "Jewish Losses in Ukraine, 1941-1944," in The Shoah in Ukraine: History, Testimony, Memorialization, ed. by Ray Brandon and Wendy Lower (Bloomington: Indiana University Press, 2008), 272-90.

${ }^{4}$ Patrick Desbois, The Holocaust by Bullets: A Priest's Journey to Uncover the Truth behind the Murder of 1.5 Million Jews (New York: Palgrave Macmillian, 2008).

${ }^{5}$ Kai Struve, Deutsche Herrschaft, ukrainischer Nationalismus, antijüdische Gewalt: Der Sommer 1941 in der Westukraine (Oldenbourg: De Gruyter, 2015). 
nationalists, with the participation of Ukrainian locals: between 60,000 and 100,000 Poles died in Volhynia and Eastern Galicia in the period 1943-1946. Thousands of Ukrainian civilians were killed by Poles in acts of retaliation. ${ }^{6}$ The majority of the remaining Polish population was resettled in Poland when the border between Poland and the USSR was redrawn at the end of World War II. However, the end of the war did not end the violence - the return of the Red Army to Galicia in the summer of 1944 set in motion the conflict between the Soviet authorities and the Ukrains'ka Povstans'ka Armiia (UPA) that would last for many years. This conflict resulted in the deportation of over 150,000 Ukrainians to the USSR and the death of thousands of Ukrainians accused of supporting partisans. $^{7}$

The above brief summary of Galician history during World War II and its immediate aftermath shows that, over the course of the war, all major ethnic groups residing in the area were subjected to mass violence: both by the occupier and by their own neighbors. Moreover, they all witnessed violence inflicted on their neighbors-in some cases by the occupier, in others, by other neighbors. With the exception of Jews, members of all ethnic groups were also perpetrators of violence. People's positions in the social hierarchy of individual groups changed over time, but the violence continued. The present chapter focuses on the war experiences of civilian Poles and Ukrainians but excludes the Jewish experience for several reasons. First of all, Jews were subjects of a total annihilation that cannot be compared with even the most brutal mass violence committed towards their Polish and Ukrainian neighbors. Second, violence towards other ethnic groups appears in Jewish testimonies only occasionally. Most of the Jews who survived the Holocaust spent the crucial war years in hiding and thus were not direct witnesses to what was happening to the Poles and Ukrainians. After the war, in turn, they focused on the suffering of their own ethnic group, and not on the suffering of the others.

For methodological reasons, I would now like to make two essential statements of a methodological as well as an ontological nature. First,

\footnotetext{
${ }^{6}$ Grzegorz Motyka, Od rzezi wotyńnskiej do "Akcji Wista”: Konflikt polsko-ukraiński 1943-47 (Kraków: Wydawnictwo Literackie, 2011).

${ }^{7}$ For an overview of the underground activity, see Grzegorz Motyka, Ukrainska partyzantka 1942-1960: działalnošć Organizacji Ukrainskich Nacjonalistów i Ukrainskiej Powstańczej Armii (Warszawa: ISP PAN, Oficyna Wydawnicza Rytm, 2006); on the postwar deportations from Western Ukraine, see Tamara Vrons'ka, Upokorennia strakhom: simeine zaruchnytstvo u karalnii praktytsi radianskoi vlady (1917-1953) (Kyiv: Tempora, 2013).
} 
despite focusing on the perspective of the witness, this chapter does not deny the fact that some Poles and Ukrainians also assumed the role of perpetrators-both during the Holocaust and during the Polish-Ukrainian conflict. Second, a bystander of the type of ethnic violence that took place in Eastern Galicia is not a person standing on the side-lines and uninvolved. Such a possibility is precluded by the very nature of this violencehappening so close to and frequently in front of local communities, often drawing them into a spiral of addictive violence. Michael Meng argued that in Central Europe it was impossible to remain outside of the Holocaust; not only Jews, but also their neighbors were constantly in the middle of the events-due to complicity, but also by means of the physical proximity of death. ${ }^{8}$

Polish researchers introduce special theoretical categories that allow for taking a new look at the bystander category-Elżbieta Janicka writes about participative witnesses (pl. świadek uczestniczacy), Roma Sendyka about outsiders (pl. postronny). ${ }^{9}$ Also Michael Rothberg's category of the implicated subject is very inspiring, defining some groups of bystanders as "implicated subjects [who] occupy positions aligned with power and privilege without being themselves direct agents of harm." 10 However, in this chapter I will claim that most of the regular bystanders to the Holocaust and other mass violence did not occupy positions of power. They were, rather, entangled witnesses, who might have benefited from the reality of the ethnic cleansing or not, but in fact were not given the choice of standing aside: they were thrown inside by the very fact of being born where they were. The notion of the "entangled bystander" describes the reality not only of the Holocaust, but also of other ethnic cleansings and outbreaks of mass violence against civilians by showing the fluidity of assigned

\footnotetext{
${ }^{8}$ Michael Meng, Shattered Spaces: Encountering Jewish Ruins in Postwar Germany and Poland (Cambridge, MA: Harvard University Press, 2011).

${ }^{9}$ Elżbieta Janicka, "Pamięć przyswojona: Koncepcja polskiego doświadczenia zagłady Żydów jako traumy zbiorowej w świetle rewizji kategorii świadka," Studia Litteraria Historica 3/4 (2014-2015), 148-224; Roma Sendyka, "Od świadków do postronnych: Kategoria bystanders i analiza 'podmiotów uwikłanych,"” in Świadek: jak się staje, czym jest?, ed. by Agnieszka Dauksza and Karolina Koprowska (Warszawa: Instytut Badań Literackich PAN, 2019), 61-82.

${ }^{10}$ Michael Rothberg, Implicated Subject: Beyond Victims and Perpetrators (Stanford, CA: Stanford University Press, 2019); see also Mary Fulbrook, "Bystanders: Catchall concept, alluring alibi or crucial clue," in Probing the Limits of Categorization: The Bystander in Holocaust History, ed. by Christin Morina and Krijn Thijs (New York: Berghahn Books, 2018), 15-35.
} 
roles-from onlooker to perpetrator, from perpetrator to starer, from bystander to supporter, from supporter to victim. This chapter tells the story of people involved in shifting roles of mass violence and of how this violence traumatized them-from both the individual and the collective perspective.

I use three main groups of sources. The first group consists of memories and diaries created during and after the war, both published and archival materials, authored by Poles and Ukrainians. The second group includes oral history interviews from the Yahad-In Unum collection created by a French project documenting places of mass executions during the Holocaust in Central and Eastern Europe. ${ }^{11}$ The third group of my sources contains over 150 interviews conducted within the project implemented in the Institute of Philosophy and Sociology of the Polish Academy of Sciences by my team and me during field studies in Eastern Galicia in 2017-2019 with people born in 1921-1939.

\section{Circles of Hell: Proximity of Violence}

To be a civilian in Eastern Galicia during World War II meant, above all, to be in constant proximity to death. It is an experience comparable to going increasingly deeper into a spiral of violence. Depending on the situation, the residents of Galicia watched various victims transported to death camps, beaten, humiliated, murdered in a number of ways, buried in mass graves; they smelled the stink of decaying bodies, they saw piles of corpses, they were forced to bury them, they looted in the ruins. Those who stood on the edge of the first circle only watched victims taken away or hurried into the unknown. In some cases, they knew that their neighbors were going to die, in others they only watched them disappear and learned about their fate much later.

At the beginning of 1940, during the first of the three deportations of Polish citizens to the USSR, entire village populations disappeared from Galicia. Dmytro Kup'iak, from the village of Jabłonówka (Yablunivka), ${ }^{12}$ saw carriages riding towards the Polish colony at night and went with

${ }^{11}$ Website https://www.yahadinunum.org/, last accessed 6 June 2020.

${ }^{12}$ Throughout the text, I use pre-war Polish names in reference to the period 1939-1945, and Ukrainian names in reference to the postwar period. When a name is given for the first time, I provide the second name in brackets. 
other villagers to take a look at empty Polish houses in the morning. ${ }^{13}$ In Bóbrka (Bibrka), Yosif Patetskyi witnessed his neighbors being thrown out of their homes and loaded onto carts with their entire families. ${ }^{14}$ In Barysz (Barysh), in September 1939, the whole village watched the Soviet interior-ministry troops Narodnyy Komissariat Vnutrennikh Del (NKVD) leading a Polish landowner from his hideout in a peasant hut and transporting him into the unknown (his name will subsequently appear on the so-called Katyń list of approximately 21,000 Polish officers and civilians murdered by the NKVD in 1940). ${ }^{15}$

The residents of Galicia were also watching the deportation of Jews in 1941 and 1942. In towns that had a railway station, they saw their neighbors being crammed into cattle cars that would take them to extermination camps. At a certain point, both victims and onlookers became aware of where these trains were going. In smaller localities, Poles and Ukrainians saw Jews being hurried down the streets to ghettos in neighboring towns, or concentrated in the middle of the village, waiting for the Germans to decide where to kill them. In July 1941, in Dobropole, Nataliia Kul'chytska (b. 1933) left her house one day only to see her Jewish neighbor being dragged out of his house with his whole family and being rushed to join a column of other Dobropole Jews taken to the neighboring village of Wiśniowczyk (Vyshnivchyk), where most of them would be murdered. ${ }^{16}$ In Wiśniowczyk, Yustyna Deretska (b. 1926) watched Dobropole and Wiśniowczyk Jews, crammed onto the former land-estate yard: “They sat there with their books and they prayed all the time and we, the children, ran to see them." 17 Poles and Ukrainians stood by the gates of their houses and watched. Kids, village outcasts and dogs followed the column of people.

${ }^{13}$ Dmytro Kup'iak, Spohady ne rozstrilianoho (Toronto: self-published, 1991), 103.

${ }^{14}$ Interview with Yosif Patetskyi, b. 1927, conducted in Bibrka in 2019 by Marta Havryshko. If not stated otherwise, the interviews were conducted in Ukraine and in Ukrainian.

${ }^{15}$ Archiwum Wschodnie Ośrodka KARTA (Eastern Archive of the KARTA Center, hereafter AW OK), AW OK II/98, Wanda Działoszyńska, 2-3; Interview with the daughter of Świdrygiełło-Świderski, Teresa Somkowicz, b. 1927, conducted in Pwllheli (Great Britain) in 2019 by Anna Wylegała. Interview conducted in Polish.

${ }^{16}$ Interview with Nataliia Kul'chytska, b. 1933, conducted in Dobropole in 2019 by Anna Wylegała.

${ }^{17}$ Interview with Yustyna Deretska, b. 1926, conducted in Osivtsi in 2018 by Wiktoria Kudela-Świątek. 
The people hurried into the unknown were beaten and humiliated. When a landowner, Władysław Świderski from Barysz, was taken to a car, NKVD officers forced his employees to spit on him and beat him. ${ }^{18}$ The humiliation of Jews-individuals or groups-was common. A womaninterviewee (b. 1927) from Hrymailiv (Grzymałów), remembers an old Jew who was abused by the Germans by the city pump; in Osowce (Osivtsi), a young Jew was placed at the head of a column of Jews, with a bouquet of thistles in his hands, and ordered to sing. ${ }^{19}$ A woman who lived in Dobryniów (Dobryniv) at that time mentions that the Germans ordered the Jews to form a circle and dance: "I even saw [my neighbors], our Laika and her daughters, and everyone who was there. You should write it down, because I was there and saw everything, when they told them to dance." 20

Deportation and humiliation announced what was about to happen. The residents of Galicia, above all, saw their neighbors die. They witnessed the deaths of individual people: in 1939 an interviewee from a village near Rohatyn watched a Polish landowner being forced to dig his own grave and then being shot by an NKVD officer. ${ }^{21}$ Jerzy Klementowski, from the village of Psary (Pryozerne), was the son of a farm worker, first employed on the estate of Count Rey, and then on the same estate when it was administered by the Germans. The German administrator was strict and organized public tortures of his Polish and Ukrainian workers in the manor yard for minor offenses. As a child, Klementowski watched tortured people through cracks in the wall, and then, with his father, took away the bodies and cleaned the yard of blood. ${ }^{22} \mathrm{~A}$ woman born in 1924 in Jaworów (Yavoriv) saw the Germans pulling out a Jewish boy her age from a house across the street and killing him on the spot, immediately after the German army had entered. ${ }^{23}$

${ }^{18}$ Interview with Anastasiia Ivantsiv, b. 1923, conducted in Barysh in 2019 by Marta Havryshko.

${ }^{19}$ United States Holocaust Memorial Museum (hereafter USHMM), RG-50.589*0244, Yahad-In Unum interview; Interview with Teodora Kanak, conducted in Osivtsi in 2019 by Marta Havryshko.

${ }^{20}$ Interview with a woman, b 1921, conducted in Stratyn in 2018 by Marta Havryshko. Some interviewees asked for anonymity and they are thus identified only by their gender and year of birth.

${ }^{21}$ Interview with a man, b. 1933, conducted in Rohatyn in 2017 by Anna Chebotarova.

${ }^{22} \mathrm{AW}$ OK II/1323/2K Klementowski Jerzy, Moje wspomnienia z lat dziecinnych z Sokolowa i Psar (1935-1943), 9.

${ }^{23}$ USHMM, RG-50.589*0193, Yahad-In Unum interview. 
However, the landscape of mass war violence was dominated by killings of the Jewish population during Operation Reinhardt. Jews were shot with machine guns and buried in mass graves at a Jewish cemetery, in a nearby forest or in a field. The shootings were usually witnessed by children. Evheniia Zalutska, from Podhajce (Pidhaitis), born in 1929, followed a column of harried Jews, climbed a tree growing next to the mass grave dug in the middle of a field, and observed the murder of several hundred people. ${ }^{24}$ Another interviewee (b. 1926) from Radłowice (Ralivka), observed the execution of local Jews from a distance, as he claims; however, he was able to determine who did the shooting, how people guarded the victims and how the bodies were laid in the dug ditches. ${ }^{25}$ Even the younger children who were not allowed to run freely by themselves were not spared the view. Lubov Shelvakh was five years old when her mother sat her on a wall so that she could better see the murder of Jews in the cemetery in Podhajce. When people heard that the Jews were being killed, they left whatever they were doing, and rushed to the scene. ${ }^{26}$ Another five-year-old, who spent the war in Skałat, observed the local "action" from the window; she saw Jews being murdered right on the street. What she remembered most was a young Jewish woman who threw her child out of the window and then jumped out herself. ${ }^{27}$ In Galicia, as in other Eastern European countries, the Holocaust was a communal genocide (for the case of Slovakia, see Hana Kubátová's chapter in this volume); it was impossible to live where it happened and not have had direct contact with death. ${ }^{28}$

Violence against representatives of other groups was more intimate and happened quietly, but it was still noticeable. The residents of Galicia, even if they did not witness the very act of murder, saw dead bodies throughout the entire war. In June 1941, bodies of Soviet prisoners brutally murdered by the retreating NKVD units were exposed to public view. Seventeen

\footnotetext{
${ }^{24}$ Interview with Evheniia Zalutska, b. 1929, conducted in 2018 in Pidhaitsi by Marta Havryshko.

${ }^{25}$ USHMM, RG-50.589*0206, Yahad-In Unum Interview.

${ }^{26}$ Interview with Lubov Shel'vakh, b. 1938, conducted in Pidhaitsi in 2018 by Anna Wylegała.

${ }^{27}$ Interview with a woman, b. 1938, conducted in Hlibiv in 2019 by Marta Havryshko.

${ }^{28}$ Omer Bartov, "Communal genocide: Personal accounts of the destruction of Buczacz, Eastern Galicia, 1941-1944," in Shatterzone of Empires: Coexistence and Violence in the German, Habsburg, Russian, and Ottoman Borderlands, ed. by Omer Bartov and Eric D. Weitz (Bloomington: Indiana University Press, 2013), 399-420.
} 
people were killed in Bóbrka. When we ask Yosif Mykytiv (b. 1923) about it, he describes how he and other boys ran to the courtyard of the local prison to see the corpses with their own eyes; the bodies lay naked, deformed, dreadful, and Mykytiv ran away screaming. ${ }^{29}$ The parents of Nataliia Zaremba, only 11 years old in 1941, took her to a prison cellar covered with blood; when I asked her why her parents would take her to this horrific place, she answered: "All kids were taken there so that they knew what the Soviets had done to our people." ${ }^{30}$ After the actions, dead bodies of Jews were commonly encountered. Józef Lesław Drecki, from Żółkiew (Zhovkva), remembers that when he went to work in December 1941, after the first deportation from the Żółkiew ghetto, he saw the body of Mrs. Taubowa, a Jewish woman he had worked for before the war, lying by a fence. ${ }^{31}$

Following the attacks of Ukrainian nationalists, people ran to see the bodies of Polish victims. In Hlebów (Hlibiv), several dozen people died overnight. An interviewee born in 1938 remembers the sight of the bodies of a Polish family murdered nearby: "I still remember us running there, little kids, in the morning, running to see them lying there, the father in the middle, and his little son by his side." 32 In Kurzany (Kuriany), Poles were killed individually, one family at a time. Mariia Koval'ska (b. 1930) remembers going to school one morning and almost tripping over the body of her dead neighbor, lying on the road completely naked. ${ }^{33}$ The next morning, her neighbor and peer, Anna Khomiak, looked with a crowd of onlookers at the charred bodies of their neighbors, piled on the threshold of their own house. She remembers that the murdered young girl was naked from the waist up. ${ }^{34}$ After 1945, there were bodies of other victims of Ukrainian partisans on the streets-for example, Russian femaleteachers or chairmen of kolkhozes - and bodies of partisans who had been caught by the Soviet authorities and displayed for the public to see. In

${ }^{29}$ Interview with Yosif Mykytiv, b. 1923, conducted in Bibrka in 2019 by Marta Havryshko.

${ }^{30}$ Interview with Nataliia Zaremba, b. 1930, conducted in Lany in 2019 by Anna Wylegała.

${ }^{31}$ AW OK II/1272/2K Józef Lesław Drecki, 21.

${ }^{32}$ Interview with a woman, b. 1938, conducted in Hlibiv in 2019 by Marta Havryshko.

${ }^{33}$ Interview with Mariia Koval'ska, b. 1930, conducted in Kuriany in 2019 by Marta Havryshko.

${ }^{34}$ Interview with Anna Khomiak, b. 1930, conducted in Kuriany in 2019 by Anna Wylegała. 
Hlibiv, one morning, on their way to school, children found the bodies of their teachers massacred, lying right on the street. ${ }^{35}$

Those who did not see bodies saw fresh graves. In Koropiec (Koropets), local Jews were murdered and buried in a deep ravine. After the shooting, Polish and Ukrainian children ran to see the newly dug graves. ${ }^{36}$ A Pole from Bóbrka, eight-years-old in 1942, sneaked out without her parents' knowledge to the village of Wołowe (Volove), a few kilometers from town, where local Jews had just died. In her memory, the earth lying on her Jewish neighbors still moves and waves. ${ }^{37}$

Those who did not see the graves, smelled them. An interviewee born in 1934 remembers that when the last prisoners of the Jewish labor camp located near her hometown of Kamionki (Kam'ianky) were shot, the locals could smell the stench of bodies decaying in mass graves for a long time. ${ }^{38}$ In Bogdanówka (Bohdanivka), bodies of murdered Jews had been burned and an awful odor of burned human bodies hovered over the village. ${ }^{39}$ There were no funerals for Jews, and the victims of the assassinations that took place at the end of the war were buried in secret. However, almost 150 Poles, mainly women and children, murdered in Barysz in the winter of 1945 by Ukrainian nationalists (Banderivtsi), were openly buried in a cemetery. Ukrainians did not attend the funeral, but the Polish survivors did. ${ }^{40}$ Entire communities participated in the public funerals of the victims of the Soviet prison massacres of 1941. Hundreds of mourners, adults as well as children, gathered at the cemeteries in Żółkiew, Bóbrka, Złoczów and in other Galician towns.

Everyone was close to violence, but some were much too close. Patrick Desbois, creator of the Yahad-In Unum archive, distinguishes three categories of witnesses to the Holocaust: indirect - those who only saw Jews led to their deaths; direct-those who saw the executions; and those requisitioned civilians who were forced by the Germans to help: to dig graves, carry bodies, sort clothes and so on. Desbois lists over 20 tasks performed

\footnotetext{
${ }^{35}$ Interview with Ol'ha Gerus, b. 1930 conducted in Hlibiv in 2019 by Anna Wylegała; interview with Teodosiia Diakiv, b. 1933, conducted in Hlibiv in 2019 by Marta Havryshko.

${ }^{36}$ Dmytro Boikiv, Perezhyte osobysto abo Mitla (Lviv: Kameniar, 2012).

${ }^{37}$ Interview with Helena Mazurs'ka, b. 1934, conducted in Bibrka in 2019 by Anna Wylegała.

${ }^{38}$ USHMM, RG-50.589*0219, Yahad-In Unum Interview.

${ }^{39}$ USHMM, RG-50.589*0224, Yahad-In Unum Interview.

${ }^{40}$ Interview with Władysław Skiba, b. 1932, conducted in 2020 in Kulin (Poland) by Anna Wylegała.
} 
by locals by order of the Germans - from preparing food for torturers to pressing the bodies into graves. ${ }^{41}$ Requisitioned civilians became the most entangled bystanders, involved not only by the very fact of seeing, smelling or hearing, but also by their-more or less willing-participation. Even before the murder, it had to be clarified as to who had to be killed. After the Poles in Barysz were killed, UPA moved to the neighboring village, where, unlike the situation in Barysz, Polish houses were widely scattered. To find the people they wanted to murder, they brought with them a Ukrainian resident of Barysz who had relatives in the village. His brother's wife (b. 1931) recalls the events in the following way:

Then they went into the valley, to the village, and took my husband's brother
with them. It was so unfair, so terribly unfair! They took him to show the houses
where Poles lived. There was his uncle, and his uncle's Ukrainian wife, and a
Ukrainian daughter, they had a little girl, her name was Olya. [...] [Them
too...?] Yes. [Even the Ukrainians?] Yes. [Didn't they know who was
Ukrainian?] I don't know... They gathered them all in the shed and... ${ }^{2}$

The Poles killed in Barysz had to be buried. There were almost 150 bodies, so the village council ordered kolkhoz workers employed as coachmen, to bury them. Thus, the bodies were transported by, for example, the 15-year-old brother of Mariia Kliotsko. ${ }^{43}$ In Kurzany, Hanna Boiko (b. 1926) remembers that her father buried a Polish family murdered in the vicinity of their home. The victims were buried in their own yard, because the Catholic cemetery was far away and times were uncertain. ${ }^{44}$ Civilians were employed to bury Jewish victims on a mass scale. Antoni Dereniowski from Narajów (Naraiiv) transported corpses from the ghetto to the Jewish cemetery and buried them in mass graves. ${ }^{45}$ In Bóbrka, Ukrainian police led Jews to the place of murder, but they picked up men from randomly chosen houses and ordered them to dig huge ditches with shovels in the local brickyard. Yosif Patetskyi's father was absent, so they picked up his

\footnotetext{
${ }^{41}$ Patrick Desbois, "The Witnesses of Ukraine or Evidence from the Ground: The Research of Yahad-In Unum," in The Holocaust in Ukraine: New Sources and Perspectives - Conference Presentations (Washington: Center for Advanced Holocaust Studies, 2013), 91-100.

${ }^{42}$ Interview with a woman, b. 1931, conducted in Barysh in 2019 by Marta Havryshko.

${ }^{43}$ Interview with Mariia Kliotsko, b. 1929, conducted in Barysh in 2019 by Marta Havryshko.

${ }^{44}$ Interview with Hanna Boiko.

${ }^{45}$ AW OK II/1267/2K Antoni Dereniowski, Narajów.
} 
teenage son instead. When the ditches were ready, the policemen chased the diggers away, murdered the Jews, and ordered people to fill in the ditches. ${ }^{46}$ In Kamionki, the Germans surrounded the Jewish labor camp during liquidation in order to prevent prisoners from escaping, then they killed the prisoners and forced local Ukrainians to take care of the bodies. A man living nearby (b. 1928) remembers that his neighbors were forced to lay bodies on large grates and then set them on fire. ${ }^{47}$

\section{At the Heart of Darkness: Towards \\ Psychological Trauma}

The consequences of the proximity of death can be traced at individual and group levels. The first reaction, especially among children, was often dread, shock and paralysis of sorts. Evheniia Sadivs'ka from Koropets (b. 1938 ) stood by the family's gate when local Jews were herded onto the street towards death. She was mesmerized and could not turn her gaze away, although, as she admits years later, it was a terrible sight. Her father forcefully pulled her away from the fence and took her home. ${ }^{48}$ Anastasiia Ivantsiv from Barysh was 22 years old and had three children when local Poles were murdered in 1945 . When the Banderivtsi raided the village, she locked herself up at home and shouted to her husband that it was the end of the world because she was being blinded by the red glow of burning houses. The following day, she was still afraid to go outside and barricaded herself at home. ${ }^{49}$

Many ran away and sought to distance themselves from what was happening. Yosif Mykytiv from Bóbrka (b. 1923) ran with other boys to see the massacred bodies of Soviet prisoners, but then ran away in horror. $\mathrm{He}$ could still see the Jews being led to the prison yard, but he would not watch them being ripped apart by an angry mob. When he came home, his mother yelled at him to stay away from everything, because it might end up badly for him. ${ }^{50}$ The parents of Nataliia Havryshkevych from Bibrka (b. 1932) were to go to the funeral of Soviet victims in July 1941, attended

\footnotetext{
${ }^{46}$ Interview with Yosif Patets'kyi.

${ }^{47}$ USHMM, RG-50.589*0226, Yahad-In Unum.

${ }^{48}$ Interview with Evheniia Sadivs'ka, b. 1938, conducted in 2019 in Koropets by Anna Wylegała.

${ }^{49}$ Interview with Anastasiia Ivantsiv.

${ }^{50}$ Interview with Yosif Mykytiv.
} 
by the entire town, but she herself insisted on staying home: "Of course I didn't go. As soon as I saw these people, I ran home and stayed there. It was awful." "51 Hanna Boiko from Kuriany (b. 1926), who was related to a Polish family murdered in the vicinity, recalls: "She was my aunt, I came, looked and ran home. I was so scared! After all, I used to visit her at home many times, and then I didn't ever go again, I was afraid to go there." 52

For those who were more sensitive or who were forced to be closer to death than they wanted, the situation became unbearable at some point. While some children who observed mass executions were unmoved, others could not forget what they had seen. Lubov Shelvakh (b. 1938) watched from the cemetery wall the murder of the Podhajce Jews. However, when she saw children being thrown alive into a mass grave, she started screaming, lost consciousness, and had to be taken home by her mother. The girl would wake up at night and wet the bed for many weeks after this event. Her mother wanted to take her to see a doctor but that was not possible during the war. ${ }^{53}$ Zygmunt Kubas from Bóbrka was 13 years old during the liquidation of the local ghetto. He wrote in his diary in the evening after the action: "I had a headache all day, I don't know if it's because of the shooting or because I had seen a lot of corpses and it affected me. I hadn't studied all day and couldn't even write in my diary." ${ }^{54}$

Not only children were deeply affected. Mariia Zamrozevych (b. 1927) from Kuriany recalls that when her father returned home from Brzeżany (Berezhany), where he witnessed the murder of local Jews, "he did not know what to do with himself." ${ }^{55}$ He kept telling his family about what he saw. The father of another interviewee from the village of Radłowice (Ralivka), who was forced to assist in the murder of local Jews, experienced a nervous breakdown, stayed in bed for a long time and did not speak to anyone. ${ }^{56} \mathrm{~A}$ resident of Chmieliska, who was forced by the Ukrainian police to bury about 50 local Jews alive during a wave of

${ }^{51}$ Interview with Nataliia Havryshkevych, b. 1932, conducted in Bibrka in 2019 by Anna Wylegała.

${ }^{52}$ Interview with Hanna Boiko.

${ }^{53}$ Interview with Lubov Shel'vakh.

${ }^{54}$ AW OK II/1347/2K, Zbigniew Kubas, Dzienniczek od dnia 1 października 1942 r. do dnia 10 maja $1944 r$.

${ }^{55}$ Interview with Mariia Zamrozevych, b. 1927, conducted in Kuriany in 2019 by Marta Havryshko.

${ }^{56}$ USHMM, RG-50.589*0207, Yahad-In Unum interview. 
anti-Jewish pogroms that swept through Galicia in July 1941, described his experience in the following way:

We all had trembling hands, and older men were as pale as ghosts. When we ran half a kilometer away from the crime scene, everyone made the sign of the cross but no one said a thing; we kept on running to get home as soon as possible. My neighbor had a heart attack and died the next day. He had participated in filling in the ditches with sand and his experiences caused his sudden death. ${ }^{57}$

While witnessing death became increasingly common with time, people did not get used to the fear of one's own death and the death of one's family. The situation of the residents of Galicia was unique because of a constant change of roles - from witness to victim, from victim to perpetrator, and then back. At any time, Poles and Ukrainians could expect to lose their shaky status as witnesses and (once more) become victims. In Delatyn (Deliatyn),

[...] at the beginning of July 1943 [t] hey dug out fresh pits at the Jewish cemetery. People are nervous because there are no Jews left in the town, unless they catch someone who is in hiding. There are rumors that the pits are meant for beggars, old people and the weak. ${ }^{58}$

It also happened that being a victim did not exclude being a perpetrator at the same time: as Marta Kurkowska-Budzan shows in her chapter in this book on the executioners from the Polish underground, in occupied Poland victims at times stood in the positions of victimizers, without losing their initial status of victims. In Galicia, every subsequent occupation was making people anxiously look out for changes in the extermination policy of the occupier. Who would be taken this time? Whom would they kill? During the German occupation, Poles and Ukrainians became convinced that when the Germans were done with the Jews, they would turn to the Slavs. Many interviewees cite Jews who were being led to die as saying: "We are the leaven, you'll be the dough" (Namy rozchyniat,' a vamy zamisiat') — or other variants of the concept. Regardless of what the Jews actually said in the final moments of their lives, these stories show the scale of the fear of those times that can only be articulated in

${ }^{57} \mathrm{AW}$ OK II $/ 1223 / 2 \mathrm{~K}$.

${ }^{58}$ Vasyl' Yashan, Pid brunatnym chobotom: Nimetska okupatsiia Stanyslavivshchyny v Drubii svitivii viini, 1941-1944 (Toronto: New Pathway Publishers, 1989), 235. 
religious-magical tropes or proverbs. ${ }^{59}$ Individuals were also afraid of being mistaken for Jews. A woman-interviewee born in 1938, with olive skin and dark-hair, when stopped on the street by the Germans, had to explain that she was Ukrainian. ${ }^{60}$

In some cases, fear would become real and understandable, while in others, it was general, not specific but still intense. A Ukrainian woman from Koropets (b. 1935), who was a young child during the war, remembers this general fear. When talking about the murder of local Jews, she said: "We were scared, we were all so scared." When asked what they were so afraid of since they were Ukrainians, she hesitated before replying: "We were simply afraid. Well, we were not Jews, but it was so monstrous, what they did to people, it was so scary." 61 The situation did not improve when the Germans left and the Soviets returned. A woman-interviewee from Koropets (b. 1927), from a mixed family, recalls:

We were scared of the KGB officers, and of those from the forest, because there were Polish, Russian and Ukrainian guerrillas. [...] Everyone was scared, people were scared of one another. And they were even more scared in mixed families, because one group would beat up another and then those beaten would retaliate. ${ }^{62}$

In some cases, fears would become more real. Anna Khomiak from Kuriany (b. 1930) says:

I remember them killing Poles, burning them, and how scared we were, how me and my mom were scared. We would run away to sleep in someone else's field, three houses away, so that they wouldn't... Because my mom was Polish, so that they would not kill us. [...] They will definitely kill us tonight, we thought. They'll set us on fire tonight... ${ }^{63}$

Was an experience of the residents of Galicia during the war simply a series of unpleasant experiences, initially shocking and then something

\footnotetext{
${ }^{59}$ For analysis of the wartime folk tales and beliefs, see Olga Belova, "Legendy o voinie: arkhetipy v sovremmenykh folklornykh narrativakh," in Problemy istorii Rosii, 10, ed. by Aleksandr Redin (Ekaterinburg: NPMP "Volot," 2013), 227-35.

${ }^{60}$ Interview with a woman, b. 1938, conducted in Hlibiv in 2019 by Marta Havryshko.

${ }^{61}$ Interview with Eva Kulykovs'ka, b. 1935, conducted in Koropets in 2019 by Anna Wylegała.

${ }^{62}$ Interview with Olena Popiv, b. 1927, conducted in Koropets in 2019 by Anna Wylegała.

${ }^{63}$ Interview with Anna Khomiak.
} 
everyone got used to, or was it an individual psychological trauma? Although there are many definitions of trauma at the individual level, most researchers agree that trauma is sudden and unexpected; it exceeds the limits of individual mental strength, and destroys the existing system of values, references and a sense of security. It is also an overwhelming experience for an individual. ${ }^{64}$ It is difficult to diagnose the mental state of the wartime residents of Galicia using the sources from the war and even the contemporary interviews. All we have are rather subjective descriptions of its external symptoms observed in other people or a subjective assessment of one's own experiences, often carried out after many years.

In the USSR, for obvious reasons, there was no research conducted after the war on the impact of the brutality of war on civilians. However, in Poland, in the period of 1945-1947, over 6000 surveys were carried out among Polish youth, examining their mental state in relation to the war. ${ }^{65}$ One cannot simply extrapolate the results of these studies to Galicia; however, attention should be paid to them for a number of reasons. First, the research covered a considerable number of young people displaced from the Eastern Broderlands, that means also from Eastern Galicia. Second, if the postwar mental state of Polish youth in general (most of whom experienced only the German occupation) was different from the mental state of Poles displaced from the Borderlands, then the group under study was likely to be in worse condition due to the multitude of occupational regimes subjected to and the experience of the PolishUkrainian conflict.

Seventy-five percent of respondents believed that they and their families suffered from a number of mental disorders - mostly their family members, but also about 20 percent of the young people themselves. The most common problems were depressive states, psychosomatic disorders (insomnia, difficulty concentrating, nervous tics), anxiety and neurotic

\footnotetext{
${ }^{64}$ Neil J. Smelser, "Psychological Trauma and Cultural Trauma," in Jeffrey C. Alexander, Piotr Sztompka, Ron Eyerman, Neil Smelser and Bernhard Giesen, Cultural Trauma and Collective Identity (Berkeley: University of California Press, 2004), 44; Robert Prince, "Historical Trauma: Psychohistorical Reflections on the Holocaust," in Children Surviving Persecution: An International Study of Trauma and Healing, ed. by Judith S. Kestenberg and Charlotte Kahn (Westport, CT: Praeger, 1998), 43-55.

${ }^{65}$ On this study, see Helena Radomska-Strzemecka, "Wpływ wojny na stosunek młodzieży do rodziny," Przeglad Socjologiczny 12 (1958).
} 
states. ${ }^{66}$ Although the majority of the issues described were rooted in direct experiences of death or mutilation of family members, a surprisingly large number of problems were related to situations when the respondents had only witnessed violence that did not affect their immediate family. Other studies show that Poles continued to dream about the war after it had ended-not only people who had been in concentration camps, had lost loved ones, had participated in combat operations-but also those who were "just" witnesses. Of the 1005 dreams collected just after the war, as many as 28.5 percent were associated with war violence. ${ }^{67}$ Other studies carried out in Poland immediately after the war show that alcoholism had become a widespread phenomenon, also among children and young people: 27.9 percent of children aged between 7 and 15 regularly drank alcohol. ${ }^{68}$ In other words, those who did not dream (or who dreamt too much) indulged in drinking to forget. According to Marcin Zaremba, author of one of the most insightful diagnoses of Polish society in the first postwar years, people drank vodka mainly because of its therapeutic value: "It was a tried and tested means of consolation in the moments of despair and defeat. [It] healed fear." ${ }^{\prime 9}$

The interviews being conducted today provide insight into the persistence of the trauma of witnessing mass violence and the sense of constant threat. The interviewees still lower their voices when talking about the Polish and Ukrainian victims of Ukrainian nationalists. They ask to go off the record when they reveal names; they stop in mid-sentence and make meaningful gestures. They cry, their voices tremble, they are unable to continue with the story when talking about the murders of Jews, especially if they saw death from up close. In some cases, they end the interview, claiming that they are unable to talk about the events that are interesting to the researcher. In some cases, after the first meeting, the family of an interviewee calls to cancel the next scheduled meeting because the interviewee had not slept all night and his/her heart ached from remembering the corpses. All of the above suggests that the war mentally wounded many residents of Eastern Galicia and does so still today.

\footnotetext{
${ }^{66}$ Biblioteka Jagiellońska (Jagiellonian Library, hereafter BJ), Przyb. 72/89, Helena Radomska Strzelecka, Charakterystyka młodzieży okupacyjnej, 53-4, 63, 65.

${ }^{67}$ Stefan Baley, "Psychiczne wpływy drugiej wojny światowej," Psychologia wychowawcza 1-2 (1948), 13.

${ }^{68}$ Marcin Zaremeba, Wielka trwoga: Ludowa reakcja na kryzys (Kraków: Wydawnictwo Znak, Instytut Studiów Politycznych PAN, 2012), 116.

${ }^{69}$ Zaremba (2012), 118.
} 


\section{Loss ANd Decay: Towards Collective \\ (Communal) Trauma}

The witnesses of mass violence also experience less obvious traumas. One way to conceptualize trauma, although not from the psychological point of view, is to treat it as a trauma of loss. The residents of Galicia lose something with each disappearing or murdered human being. This process can be perceived on the individual level or from the perspective of an entire community. The most basic level of a trauma of losing is the loss of people who are important for the individual or the community. This was most painfully felt in many mixed rural communities existing before 1945, where marriages between Poles and Ukrainians were common, and the division into Polish and Ukrainian families was purely formal even up until the early 1930s. ${ }^{70}$

Inhabitants in Polish villages in Galicia, unlike in the neighboring Volhynia, were rarely slaughtered in entirety, but most probably there were no villages where no Poles were murdered. Those who did not die would have to leave- and, hence, they would still disappear from the community. In Hlibiv, where several dozen local Poles were killed during the war, out of several hundred, Ol'ha Gerus (b. 1930) testifies with hesitation: "It was so bad when they beat up those Poles. There were many mixed families. They left, and one had no family anymore." ${ }^{\prime 1}$ Another interviewee from Rohatyn (b. 1933) refers directly to her experience: "Our entire family is gone. My mother's sister left [for Poland after the war] with her husband, and Stach, and Władzio, and Maniuśka, and the youngest, four children." 72

The most severe loss is the loss of one's family, but residents also mourn their neighbors and friends. Stefania Shkvaryliak from Koropets (b. 1930) remembers her childhood best friend and neighbor, a Polish girl named Helka. After Helka left with her whole family after the war, Stefania did not make any new friends for a long time, and she corresponded with

\footnotetext{
${ }^{70}$ For more about the national relations in Galicia, see Olga Linkiewicz, Lokalnośc i nacjonalizm: Społeczności wiejskie w Galicji Wschodniej w dwudziestoleciu międzywojennym (Kraków: Universitas, 2018).

${ }^{71}$ Interview with Ol'ha Gerus.

${ }^{72}$ Interview with a woman, b. 1933, conducted in Rohatyn in 2017 by Wiktoria Kudela-Świątek.
} 
Helka for many years. ${ }^{73}$ The best friend of a Ukrainian woman (b. 1927) from the village of Usznia (Ushnia) was her Jewish neighbor; they went to school together, grazed cows together and grew up together. Like almost all Jews in Usznia, Tonia was murdered in the summer of 1942-probably with the participation of her Ukrainian neighbors. ${ }^{74}$ Her Ukrainian friend has been crying over Tonia ever since. Teodora Kanak from Osivtsi (b. 1927) remembers that her father refused to hide their Jewish neighbor, but afterwards he cried and searched for the corpse in the plundered Jewish houses. We may only guess that while he did not find enough strength in himself to risk his own family and help his neighbor, he regretted it and felt he had failed the Jew, breaking long-lasting rules of neighborly loyalty. ${ }^{75}$ One of the most shocking testimonies regarding the mourning of murdered neighbors is the conversation of two Ukrainian women from Kuriany, recalling the murder of their Polish neighbors:

It was summer.. Yes, it was summer, what a summer that was. I still remember that Czesiek was at my place, they were at our place. After all, they were our friends, we sang songs until the evening, the girls were so cool... They were at our place on that day... What despair it was afterward! We sang, we sat outside and sang. And they were murdered at night. In the morning... My husband's father, he lived close to them, he dug a pit, put everyone inside, buried them, and that was it. ${ }^{76}$

Their memories show the uncertainty of life and death during the war: in the evening, your neighbor sits in your courtyard and sings songs, in the morning you go and see his dead body-and "that is it." Loss also takes place at a group level when communities lose members who had particular social or economic roles. In many communities, representatives of specific ethnic groups had dominated certain professions before the war. When Poles or Jews were killed, there was immediately a shortage of doctors, teachers, traders and shoemakers; the absence of doctors (and veterinarians) was perhaps the most severe outcome. At some point, the Germans lifted the ban on the treatment of Aryan patients by Jews because, after the

\footnotetext{
${ }^{73}$ Interview with Stefaniia Shkvaryliak, b. 1930, conducted in Koropets in 2019 by Anna Wylegała.

${ }^{74}$ USC Shoah Foundation, Visual History Archive, interview with Noyach Auerbach, no. 11568 .

${ }^{75}$ Interview with Teodora Kanak.

${ }^{76}$ Interviews with Hanna Boiko and Mariia Kovals'ka.
} 
deportation of most of the Polish intelligentsia to Siberia in 1939-1941, there was no one left who could treat patients. Baruch Milch, a Jewish doctor who was hiding in the vicinity of Tłuste (Tovste) throughout the war, recalled that as soon as he came out of hiding after the liberation, he was flooded with requests for medical help. ${ }^{77}$ Vira Holinach (b. 1934), who lived in a village near Tovste after the war, remembers that her mother almost lost her injured leg because her family was unable to find a doctor to take care of the wound. ${ }^{78}$

There was a shortage of teachers after the war, which is not surprising since the Soviets predominantly targeted Polish and Ukrainian intelligentsia, and the Polish teachers who survived left Galicia as soon as possible when the Soviets returned. An interviewee from Rohatyn testifies that there were no "real" teachers after the war because they were killed by "one or the other." 79

However, ethnic and political cleansing did not affect just the intelligentsia. In Galicia, during and immediately after the war, there was a shortage of traders, shopkeepers and craftsmen. In pre-war Stratyń, there was a bakery run by a Jew. When he was murdered by the Germans, the bakery remained closed, and it was never reopened. In Szczerzec (Shchyrets), the majority of Jewish-owned stores stood empty for several years. ${ }^{80}$ Shortly after the war, Galician towns and villages were ghosttowns. Many of them irretrievably lost their town status and underwent secondary agrarianization. This was the case for many towns mentioned in this chapter - the populations of Koropets, from which Poles and Jews had disappeared, or Barysh, where a number of Poles had been murdered and the rest had left, decreased by more than half. Felsztyn, a small town before the war (the village of Skelivka in Lviv region after the war), was bitterly described in 1946 by a Ukrainian diarist as "once a town, today empty." 81

${ }^{77}$ Baruch Milch, Testament (Warszawa: Ośrodek KARTA, 2001).

${ }^{78}$ Interview with Vira Holinach, b. 1934, conducted in Tovste in 2018 by Nataliia Otrishchenko.

${ }^{79}$ Interview with a man, b. 1922, conducted in Rohatyn in 2017 by Anna Chebotarova. On the shortage of staff in education, see Tamara Halaichak, ed., Kul'turne zhyttia v Ukraini: Zakbidni zemli - Dokumenty $i$ materialy, Vol. I: 1939-53 (Kyiv: Naukova Dumka, 1995), 52-3.

${ }^{80}$ Interview with a woman, b. 1923, conducted in Stratyn in 2017 by Marta Havryshko; USHMM, RG-50.589*0173, Yahad-In Unum interview.

${ }^{81}$ Lev-Petro Savchyns'kyi, Spohady (Lviv: Krai, 2007), 103. 
The residents of Galicia lost much more than significant people and their hometowns in the condition they had known them before the war. As the war went on, they lost their sense of security - they were waiting for the next occupier, a militia or a group of people aiming to destroy the ethnic or religious group they belonged to. They stopped trusting each other because it might turn out, at any time, that a neighbor wanted to take their life, or another neighbor was collaborating with the occupier and could show the latter who to arrest and kill. They lost what Piotr Sztompka calls a moral bond, understood as a special type of social bond that consists of loyalty, trust and solidarity. ${ }^{82}$ Ol'ha Gerus from Hlibiv (b. 1930) mentions her father's cousin—a Pole who regularly eavesdropped on their conversations to find out which Poles the local Banderivtsi were planning to kill this time. ${ }^{83}$

The fact that a vast majority of acts of mass violence taking place in Galicia happened outside the state apparatus of violence had an extremely destructive effect on the integrity of local communities, a phenomenon that Natalia Aleksiun describes as "intimate violence." 84 The Germans were planning and controlling the Holocaust, but they engaged the Ukrainian police to perform auxiliary tasks that might involve shooting. And the pogroms that swept through Galicia in the summer of 1941 were the work of the neighbors of Jews: Ukrainians and Poles. The case of purges of Poles and retaliatory actions against Ukrainians was similar; in some cases, they were carried out by locally unknown guerrilla units, but much more often by locals, the victims' neighbors.

As a result, social order, understood as a system of norms and values that regulates social coexistence, also disappeared from Galicia. The more and less important norms became unstable. Consent of and growing indifference to violence emerged. More and more children and teenagers became perpetrators of atrocities. They not only witnessed executions, but also contributed to the deaths of their neighbors. Józef Anczarski, a Catholic priest who spent the war at the parish in Dobropole, describes in his diary how in October 1942 rural teenagers tortured and then murdered in front of the entire community an old Jewish woman who came to

\footnotetext{
${ }^{82}$ Piotr Sztompka, "Kulturowe imponderabilia szybkich zmian społecznych: zaufanie, lojalność, solidarność," in Imponderabilia wielkiej zmiany: Mentalność, wartości i więzi społeczne czasów transformacji, ed. by Piotr Sztompka (Warszawa: WN PWN, 1999), 265-82.

${ }^{83}$ Interview with Ol'ha Gerus.

${ }^{84}$ Natalia Aleksiun, "Intimate Violence: Jewish Testimonies on Victims and Perpetrators in Eastern Galicia," Holocaust Studies: A Journal of Culture and History, 23:1-2 (2016), 17-33.
} 
the village. ${ }^{85}$ Teenage Ukrainian boys participated in the murder of Polish residents of the village of Korościatyn (Korostiatyn), an act carried out in February 1944: Poles who survived the slaughter claimed that while the men murdered the inhabitants of one household after another, the boys robbed the victims and set fire to their houses. ${ }^{86}$

The act of watching monstrous public murders made further killings easier to commit and to watch. ${ }^{87}$ Many researchers argue that the crimes committed by the UPA on Poles in Galicia and Volhynia happened because the perpetrators had had previous training with the Ukrainian police used by the Germans during the Holocaust. ${ }^{88}$ The sources clearly provide an image of a society in a state of anomie, morally and socially instable, in economic chaos, while children's games of those times show how á rebours was the world of post-violent Galicia. Galician children-Polish, Ukrainian, and sometimes even Jewish, did not play "policemen" or "school." They played "round-ups," "shooting Jews" and "running away from Germans and Russians." The murdered "Jews," played by sparrows or mice, were buried in mass graves behind barns. ${ }^{89}$

All of the above, the loss of loved ones and neighbors, the loss of a sense of security, the collapse of a stable social structure, anomie and moral chaos, goes far beyond the definition of psychological trauma and should be defined rather as a kind of collective or communal trauma affecting not the individual but the entire community. According to Kai Erikson, collective trauma is "a blow to the basic tissues of social life that damages the bonds attaching people together and impairs the prevailing sense of

${ }^{85} \mathrm{AW}$ OK II/1224/2K, ks. Józef Anczarski, Kronikarskie zapisy z lat cierpień, grozy, zbrodni i ludobójstwa narodu, 1939-1946, 215.

${ }^{86}$ Jan Zaleski, Kronika życia, ed. by Tadeusz Isakowicz-Zaleski (Kraków: Małe Wydawnictwo, 2010), 48-9; Motyka (2006), 383.

${ }^{87}$ This can be described as the normalization of violence. See e.g., Jared McBride, "Peasants into Perpetrators: The OUN-UPA and the Ethnic Cleansing of Volhynia, 1943-1944," Slavic Review, 75:3 (2016), 630-54.

${ }^{88}$ Cf. Grzegorz Rossoliński-Liebe, Stepan Bandera: the life and afterlife of a Ukrainian nationalist: fascism, genocide, and cult (Stuttgart: ibid. Verlag, 2014). Jan T. Gross rightly noticed that each act of plunder during the war made the next one easier: it appears that this statement can refer to any violence, see Jan T. Gross, "Social Consequences of War: Preliminaries to the Study of Imposition of Communist Regimes in East Central Europe," East European Politics and Societies 3:2 (1989), 198-214.

${ }^{89}$ AW OK II/1347/2K, Zbigniew Kubas, Dzienniczek od dnia 1 października 1942 r. do dnia 10 maja $1944 r$. 
communality." 90 Mass violence in Galicia certainly destroyed the social world. It took many years to restore and, in some respects, was never fully rebuilt. Framing this specific aspect of trauma as communal obviously refers to Omer Bartov's concept of communal genocide but goes beyond his definition. Communal trauma means both traumatic experience by the entire community and the destruction of the community as such. The community falls to pieces of entangled individual bystanders.

\section{Living with the Dead: Long-Lasting Post-Traumatic FOLLOW-UP}

The third element of post-violence trauma consists of the necessity to live in places of mass death and, until very recently, to remain silent about it. Silence began during the war: people watching Jews being murdered did not speak, neighbors burying Polish victims in a rush did not speak, finally, parents of the UPA partisans looking at the bodies of their children, publicly displayed by the Soviets, did not speak (this was one of the methods used by the authorities to identify and repress the families of guerrilla members). Silence was safer than showing emotions, although it took a mental toll. Teodora Kanak from Osivtsi (b. 1927) recalls her feelings from the day when Jews were taken away from her hometown:

They cried a lot as they were hurried along. [...] And I cried a lot too, and then this soldier says to me: "Don't cry, or you'll go with them." So, I suppressed everything because I was scared. I was just a kid. This is what happened. ${ }^{91}$

An interviewee from Kuriany (born 1927) answers the question of how people reacted to the fact that the Germans took Jews from the village: "What were they supposed to say? They turned their gaze away. We were scared to even look at them." 92

After the war, the only (former) residents of Galicia who could openly and publicly speak about their war experiences were Jewish survivors who managed to emigrate to the West. Poles who were displaced to communist Poland and Ukrainians who remained in Soviet Ukraine were both

\footnotetext{
${ }^{90}$ Cited in Jeffrey C. Alexander, "Towards a Theory of Cultural Trauma," in Alexander et al. (2004), 5 .

${ }^{91}$ Interview with Teodora Kanak.

${ }^{92}$ Interview with Mariia Zamrozevych.
} 
deprived of that option. For obvious reasons, in both countries it was impossible to publicly discuss the topic of Soviet victims who were deported and then died in Siberia, were arrested and executed by the NKVD or were the UPA partisans who were murdered or died fighting Soviet troops. On the other hand, Polish victims of ethnic cleansing and Ukrainian victims of retaliatory actions could not be officially commemorated because the wartime Polish-Ukrainian conflict has been erased from official Polish and Soviet historiography. The case of the memory of the Holocaust was not so obvious. Neither in Poland nor in the USSR was the Holocaust denied as such; however, the official policy of the USSR was to treat the murdered Jews as civilian victims of the war, a position which contributed to downplaying the crimes perpetrated against this group..$^{93}$

As a result, in the postwar years, the extremely difficult biographical memory of violence, often co-existing with individual psychological trauma, could not be translated into public commemorative practices, which might have had a therapeutic role. Both people who left Galicia and those who stayed behind had to deal with their traumatic experiences on their own. Nonetheless, local communities were not completely silent: people did not speak in public, but they could talk in a group of people they trusted. The fact that mass violence was discussed not only by mentioning "their" victims is evidenced by both the content of presently conducted interviews and the circumstances of the field studies. In the majority of towns where we conducted fieldwork, we heard detailed descriptions of local executions, not only from witnesses but also from people who were not present at the crime scene, namely, older as well as younger interviewees who were born after the war. Nataliia Havryshkevych (b. 1932) from Bibrka describes in detail the murder of Bibrka Jews in 1942 in the nearby village of Wołowe, but when asked if she saw it with her own eyes, she says indignantly that she did not, since she was a child. When I ask if her mother saw it, she again says no. Rather, the mother heard about it, and

\footnotetext{
${ }^{93}$ On the official memory of the Holocaust in the USSR, in particular in Western Ukraine, see Zvi Gitelman, "Soviet Reactions to the Holocaust, 1945-1991," in The Holocaust in the Soviet Union: Studies and Sources on the Destruction of the Jews in the Nazi-Occupied Territories of the USSR, 1941-1945, ed. by Lucjan Donroszycki and Jeffrey S. Gurock (Armonk: M.E. Sharpe, 1993), 3-28; Tarik Cyril Amar, "A Disturbed Silence: Discourse on the Holocaust in the Soviet West as an anti-Site of Memory," in The Holocaust in the East: Local Perpetrators and Soviet Responses, ed. by Michael David-Fox, Peter Holquist and Alexander M. Martin (Pittsburgh: University of Pittsburgh Press, 2014), 158-84.
} 
told her ten-year-old daughter everything in detail. ${ }^{94}$ The interviews recorded by the Yahad-In Unum team provide much corresponding data.

Very often, our interviewees are surprised by our question concerning the source of the precise information about events they had not witnessed, and answer that everyone saw everything, people talked about it in secret, how could we not know? The case of an interviewee from Hlibiv, where the local UPA partisans murdered several dozen local Poles in total, was very symptomatic. She was very reluctant to share her knowledge on this subject, but her granddaughter who was escorting us to the center of the village, told us about the crimes in detail: who died, who murdered whom and how, how the corpses were transported to the cemetery and how blood was dripping from the wagon. ${ }^{95}$ It was obvious that she had heard it from her grandmother many times. After the war, knowledge of mass crimes against members of a local community-Ukrainians, Poles and Jews-was an "open secret," hidden from others for various reasons and absent from official discourse. ${ }^{96}$

Public silence also played a protective role in the mutilated Galician communities. As Hana Kubátová accurately notes in her chapter on Slovakia, after the war "former victims and perpetrators were expected to find a place as neighbors again." In Galicia, this necessity was even more acute. On the one hand, people co-responsible for crimes were protected from punishment, and, on the other, they could reintegrate into the local community in line with the principle that everyone knows, but because the victims are not here anymore, no one speaks up about it. In the majority of the communities under study, the oldest interviewees knew very well which local teenagers had been in the Ukrainian police and had participated in the shooting of Jews, and which later joined the guerrillas and killed Poles, and often these were the same people. In some cases, they were tried and convicted in postwar trials of collaborators or arrested as part of the fight against the Ukrainian underground, but most of the time they managed to avoid prosecution and continued to live in their hometowns.

For the community, the above mechanism enabled it to rebuild after the war, but for people from mixed families who stayed in Galicia after the

\footnotetext{
${ }^{94}$ Interview with Nataliia Havryshkevych.

${ }^{95}$ Interview with Ol'ha Gerus; informal conversation with her granddaughter.

${ }^{96}$ Marta Kurkowska-Budzan, "Imaging Jedwabne: The Symbolic and the Real," Polish Sociological Review 137:1 (2002), 113-7.
} 
war, it deepened their war trauma. Apart from the memory of the sense of danger, the need to escape, and the loss of loved ones, they had to deal with the fact that, after the war, men who had wanted to kill them or had even murdered members of their family, could walk down the streets of their town. Anna Khomiak from Kuriany (b. 1930), who hid at the end of the war with her Polish mother and sisters (her father was a Ukrainian, so her brother was also considered a Ukrainian, unlike female members of the family) from her neighbors who had joined the UPA and hunted for local Poles, gave a symptomatic interview. When asked how she was able to look those neighbors in the eye after the war, she claimed that after the war everything calmed down and was normal. But when I ask for names, she says she has forgotten them (while she remembers other names without a problem). ${ }^{97}$ Both Poles and Ukrainians from Galicia were not only entangled in what was happening there during the war, but also in memory of the violent past for many years after the war. Thus, the silence they experienced for so many years was a very complex phenomenon grounded in diverse reasons. Only in part did it emerge from the direct psychological trauma; another reason was politically and socially (communally) motivated repression from outside.

Unlike the Poles who were displaced from Galicia and took their sense of injustice with them, Ukrainians (and people from mixed families, such as Anna Khomiak) who stayed in Galicia, had to face many indirect and temporarily postponed traumas after the war. They had to learn to be silent; they had to learn to live alongside their perpetrators in order to allow their local community to survive; they had to live in crime scenes where the first murders of Polish landowners and the last executions of the UPA partisans had taken place. In many cases, they had to live in houses that belonged to a murdered person, or even literally live on someone's ashes.

The fact of taking over a house or an apartment after the war that had belonged to a Jew or a Pole no longer stirs emotions. It is not considered shameful and most interviewees openly call their own or their neighbors' houses "Jewish" or "Polish." This is due to two facts. First, in postwar Galicia, local authorities were responsible for distributing the nondestroyed houses that had belonged to the murdered or displaced via administrative orders. In very few cases had the new owner contributed in any way to the death or expulsion of the previous one. Second, the level of

\footnotetext{
${ }^{97}$ Interview with Anna Khomiak.
} 
war destruction of residential buildings forced people to forget about their doubts in order to secure a roof over their heads.

The management of space around mass graves proved to be more problematic. In Galicia, as in the whole of the USSR, there were no mass exhumations of the murdered, but the majority of graves remained unmarked (often to this day). Under a mass campaign in the 1960s, many of the Jewish cemeteries in Galicia, where executions took place during the war, were removed to make space for public buildings. ${ }^{98}$ In Shchyrets, a workers' hotel was erected on the site of a mass grave. At the Jewish cemetery in Barysh, where Jews were also murdered, the matzevah were razed to the ground and kolkhoz farm buildings were erected. A woman born in the 1940s testifies in dismay: "It's all done, there's not a sign there. They dismantled all grave markers and removed tombstones with inscriptions, when they were building the kolkhoz, the farm. This is now the foundation for the stables; we saw tombstones with Jewish inscriptions." 99

In addition to public buildings, residential houses are also being built on mass graves. In a picturesque ravine not far from the center of Koropets, where Jews were shot, a local surgeon built his villa in the 1990s. Older residents shake their heads in disbelief, as if to say "how could he?" when discussing the matter. The house in Kuriany, on the doorstep of which a Polish family murdered in 1945 is buried, has changed owners several times and is currently home to a family that came from outside the village community. We were unable to talk to them, so we do not know if they are aware of the fact that the bodies of the hastily buried murdered family members are still there. In Zhovkva, a private owner built a house on the part of kirkut that had not been turned into a marketplace. Rumor has it that the house is cursed, that someone hanged himself there and that Jewish bones were found when the foundations were being dug. In other cases, mass graves had appeared under one's window. A woman-interviewee from the village of Pidhaichyky (Podhajczyki) did not choose to live next to the mass grave of her Jewish neighbors: Germans simply dug it within 100 meters from her house and she had to live with this fact ever after. ${ }^{100}$

\footnotetext{
${ }^{98}$ This was part of a wider campaign taking place in the USSR and the Soviet bloc. In Poland, for example, German cemeteries were removed under the 1964 decree of the Minister of Public Affairs, see Meng (2011), 141.

${ }^{99}$ Informal conversation with a woman, b. around 1945, conducted in Barysh in 2019 by Marta Havryshko.

${ }^{100}$ USHMM, RG-50.589*0213, Yahad-In Unum interview.
} 
For many years after the war, the residents of Galicia were unable to forget about mass death, because they have literally lived on the bones of the victims - their own and others', and they have met the perpetrators on the streets-their own and others'.

\section{Conclusions}

To circle back to the main question of this chapter: what kind of trauma was experienced in Eastern Galicia by witnesses of mass violence, Poles and Ukrainians? First, some of them-more sensitive ones and/or those who have had particularly close contact with death and violence-experience individual psychological trauma with all its psychological and psychosomatic symptoms. It appears that the mental experiences of the witnesses had a gradation, and, while they did not always develop into a full traumatic experience on the scale from indifference to trauma, they were closer to the latter. Certainly, it should be emphasized that the psychological traumatization of one part of the group does not mean that another part of the group does not experience opposite emotions or is even guilty of perpetration.

The second aspect of post-violence trauma is collective trauma. The goal of this chapter has been to conceptualize it primarily as trauma of losing that affects the entire community, which loses its members (who have socially and economically important roles), a sense of security, the existing social structure, integrity and moral coherence. This trauma is less direct, and various members of the community experience it in varying degrees. Piotr Sztompka's theoretical concept of the trauma of social change helps to understand it. ${ }^{101}$ Sztompka analyzes it most fully using the example of the Polish political and economic transformation after 1989, but his insights can be applied to any significant social change, such as the murder of several dozen percent of the Galician community over a few years. Sztompka unequivocally argues that major transformations and social crises are almost always accompanied by atrophy of social bonds and other elements of the social world including the structure and the system of values that define the shape of the community and society. It appears that in the long-term perspective, this aspect of post-violence trauma, although less obvious, was more significant for Galicia as a social organism than a

${ }^{101}$ In English, see Piotr Sztompka, "Cultural Trauma: The Other Face of Social Change," European Journal of Social Theory 3:4 (2000), 449-66. 
number of individual psychological traumas experienced by its residents, because the trauma of losing affected everyone, not only the more sensitive ones. All this makes collective trauma in Galicia also communal.

Galician mass violence and death at the collective level might have been easier to work through if it had received the dimension of cultural trauma, as understood by Jeffrey C. Alexander. However, it did not, for a number of reasons. For collective trauma to become a cultural trauma it should be remembered, preferably also in the dimension of intergenerational transmission. The memory of it should acquire a culturally significant status, that is one that produces a powerful narrative of collective suffering, loss and tragedy that is recognizable to all members of the community. Finally, such memory should be associated with a strong negative affect such as pain, shame or guilt. According to Neil J. Smelser, "cultural traumas are for the most part historically made, not born." 102 In Galicia, the collective trauma of losing has not evolved into cultural trauma for two reasons. First, the totalitarian state does not provide conditions for an agent of memory. In a democratic state, it is the state or a structured social or ethnic group that finds it important to build a narrative about this particular trauma. Secondly, after the collapse of the USSR, when such opportunities arose, there were many other candidates for cultural trauma; the collapse of the USSR competes with Soviet repressions or the Chernobyl disaster, and the trauma of war violence stands no chance in this competition.

The third element of post-violent trauma is postwar silence on the one hand, and the necessity to continue living in places contaminated by violence on the other (living with the dead). In postwar Galicia there were almost no villages, towns or other sites without mass and individual graves; they were everywhere, just like the memory of those who were murdered and those who murdered - their own people and others.

These three elements of trauma, individual psychological trauma, collective and communal trauma of losing, and long-lasting trauma of silence and the necessity of "living with the dead," combine to form a multidimensional trauma of constant mass violence. Representatives of various groups of Galician residents, those who left after 1945 and those who remained, have experienced it to various degrees, but it has touched

${ }^{102}$ Smelser (2004), 36-7. 
everyone. To turn to the words of one of the women-interviewees: "it has never been the same since they killed everyone." 103

Acknowledgment The research for this chapter was funded within the project "Social anthropology of the void: Poland and Ukraine after World War II", financed by the National Program for the Development of the Humanities in Poland, no. 0101/NPRH3/H12/82/2014.

${ }^{103}$ Interview with Yosifa Fedorovych, b. 1927, conducted in Vyshnivchyk in 2018 by Anna Wylegała.

Open Access This chapter is licensed under the terms of the Creative Commons Attribution 4.0 International License (http://creativecommons.org/licenses/ by $/ 4.0 /$ ), which permits use, sharing, adaptation, distribution and reproduction in any medium or format, as long as you give appropriate credit to the original author(s) and the source, provide a link to the Creative Commons licence and indicate if changes were made.

The images or other third party material in this chapter are included in the chapter's Creative Commons licence, unless indicated otherwise in a credit line to the material. If material is not included in the chapter's Creative Commons licence and your intended use is not permitted by statutory regulation or exceeds the permitted use, you will need to obtain permission directly from the copyright holder.

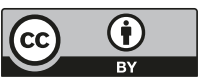

